6. Сидоров В.С. Экологическая биохимия рыб. Липиды. - Л.: Наука, 1986. - 240 с.

7. Хандожко Г.А., Вертей В.В., Васильев А.А. Система садков для выращивания рыбы // Патент RUS 75540. 2008.

8. Эффективность применения в кормление двухлеток карпа повышенной дозы йода в условиях садкового выращивания /А.А. Карасев [и др.] // Аграрный научный журнал. - 2015. - №10. - С. 8- 10.

9. Яржомбек А.А., Щербина М.А., Шмаков Н.Ф. Временные рекомендации по определению продуктивных свойств кормов для рыб. - М.: ВНИРО, 1982. - 35 с.

Мунгин Владимир Викторович, $\partial-p$ c.- $x$. наук, проф. кафедры зоотехнии им. профессора С.А. Лапшина, Нацио- нальный исследовательский Мордовский государственный университет имени Н.П. Огарёва. Россия.

Арюкова Екатерина Александровна, канд. с.-х. наук, преподаватель кафедры зоотехнии им. профессора С.А. Лапшина, Национальный исследовательский Мордовский государственный университет имени Н.П. Огарёва. Россия.

Гибалкина Надежда Ивановна, канд. с.-х. наук, доцент кафедры зоотехнии им. профессора С.А. Лапшина, Наичиональный исследовательский Мордовский государственный университет имени Н.П. Огарёва. Россия.

430904, г. Саранск, р.п. Ялга, ул. Российская, 31.

Тел.: (8342) 25-41-65.

Ключевые слова: карп; сырой жир; кормление; прирост массы; комбикорм; жмых; шрот; съедобные и несъедобные части.

\title{
INFLUENCE OF CRUDE FAT IN PRODUCTIONAL FEED-STUFF ON PRODUCTIVITY AND SLAUGHTER OF MARKETABLE CARP
}

Mungin Vladimir Viktorovich, Doctor of Agricultural Sciences, Professor of the chair "Zootechnics named after Professor S.A. Lapshin", National Research Mordovia State University named after N.P. Ogarev. Russia.

Arykova Ekaterina Aleksandrovna, Candidate of Agricultural Sciences, Senior Spe-cialist of the Department of Geology and Licensing of Natural Resources in the Republic of Mordovia, National Research Mordovia State University named after N.P. Ogarev. Russia.

Gibalkina Nadezhda Ivanovna, Candidate of Agricultural Sciences, Associate Pro-fessor of the chair "Zootechnics named after Professor S.A. Lapshin", National Research Mordovia State University named after N.P. Ogarev. Russia.

Keywords: carp; crude fat; feeding; weight gain; feed-stuff; presscake; protein meal.
The data on application in feed of commodity carp of mixed fodder with the opti-mum level of raw fat are given. It is established that the application of mixed fodder with a fat level of $5 \%$ of dry matter contributes to an increase in the total body weight of fish by $24.5 \%$, and the optimization of digestion processes contributes to a decrease in feed costs by $28.4 \%$ per unit of growth. It is shown the profitability of fish products production with the application of sunflower meal (instead of an equivalent of meal amount) in the feeding of carp and quantitative indicators of the edible part of fish, in second group they are higher by $5.3 \%$ in relation to the control.

удк 636.4.082

\section{ВЛИЯНИЕ ПОРОДЫ И ГЕНОТИПА НА ПРОДУКТИВНЫЕ КАЧЕСТВА ХРЯКОВ-ПРОИЗВОДИТЕЛЕЙ}

\author{
ПОГОДАЕВ Владимир Аникеевич, ВНИИОК - филиал ФГБНУ «Северо-Кавказский Федераль- \\ ный научный аграрный изентр»
}

РАЧКОВ Игорь Геннадьевич, ВНИИОК - филиал ФГБНУ «Северо-Кавказский Федеральный научный аграрный центр»

Выявлена продуктивность хряков-производителей в зависимости от породы и генетического профиля по ДНК-маркерам: ген рианодинового рецептора (RYR-1); ген эстрагенового рецептора (ESR); ген мясной продуктивности (Н-FАВР). Дана оценка племенной ценности животных на основе ДНК-маркеров, позволяющая получить информацию о генотипе животного и его продуктивных качествах. Представлены данные, подтверждающие целесообразность проведения генетической диагностики воспроизодящей части стада, как хряков, так и свиноматок, которые позволяют объективно выявлять предпочтительные для селекиии аллели. Отбор таких животных в качестве родительских пар позволит значительно повысить продуктивность. Помимо генной диагностики желательно при включении хряков-производителей в воспроизводтельный процесс учитывать количественные и качественные показатели спермопродукиии, исходя из реального возраста животных и породности. Предпочтительными с точки зрения селекции являются генотипы ВB (ген ЕSR), HНdd (ген H-FABR) u NN (ген RYR-1). Генотипы AB, HhDd u Nn выше указанных генов являются промежуточными для селекции, а генотипы AA, hhDD и пn - нежелателъными или недопустимъми для дальнейшей селекции.

Введение. В последнее годы в мировой селекции происходят значительные изменения в технологиях оценки племенной ценности сельскохозяйственных животных. В первую очередь эти технологии ассоциируются с геномным сканированием хозяйственно ценных признаков продуктивности.
В 1984 г. Кери Мюллис впервые предложил метод амплификации фрагментов ДНК, который в дальнейшем получил название полимеразной цепной реакции - ПЦР (polymerizechainreaction - PCR). В 1998 г. C.S. Haley и P.M. Visscher предложили термин «геномная селекция» [9], а в 2001 г. T.H.E. Meu- 
wissen c соавторами [8] разработали принципиально новую методологию оценки племенной ценности животных на основе ДНК-маркеров.

Известно, что большая часть хозяйственно ценных селекционных признаков имеет полигенный характер, т.е. контролируется множеством генов. В то же время имеются гены, а точнее аллели этих генов, вклад которых в проявление того или иного признака продуктивности, независимо от воздействия факторов внешней среды, имеет четко выраженный эффект. Такие гены называются основными генами количественных признаков (Quantitative Trait Loci, QTL). Выявление различий между животными по аллельным вариантам в локусах ДНК делает возможным проводить отбор животных непосредственно по генотипам, т.е. по генетическим маркерам. Такой подход получил название маркерной селекции или MAS-селекции (Marker Assisted Selection, MAS) [2, 5].

Фундаментальные знания в области молекулярной генетики позволили к 2010 г. расшифровать геномы основных видов сельскохозяйственных животных (крупного рогатого скота, свиней, овец) и проводить генотипирование по тысячам ДНК-маркеров. Наиболее удобным для использования в практической селекции является SNP (Single Nucleotide Polymorphism), так называемый снип, или однонуклеотидный полиморфизм, т.е. отличие в последовательности ДНК размером в один нуклеотид (А, Т, С или $\mathrm{G})$, которое может быть причиной изменения последовательности чередования аминокислот в белке. Это в свою очередь изменяет в ту или иную сторону проявление признака продуктивности. Для более быстрого получения информации о генотипе животного компании Illumina и Affymetrix разработали ДНК-чипы, позволяющие генотипировать животное более чем по 50 тысячам SNP-маркеров [5].

Самым распространенным и признанным в SNP-маркерах является лучший линейный несмещенный прогноз или BLUP - best linear unbiased prediction и Animal model, доля которого и определяет племенную ценность (Total Breeding Value, TBV) [6]. Геномная оценка (Total Genomic Breeding Value, TGBV) животного складывается из суммирования показателей общего индекса племенной ценности с учетом коэффициентов значимости каждого SNP-маркера.

Генотипирование животных позволило установить наследование в генах определенных ценных аллелей практически сразу после рождения, исключив фенотипическую оценку в период продуктивного использования. Таким образом, прогнозировать племенную ценность животного можно в самом раннем возрасте, что на порядок повышает эффективность селекционного отбора $[1,3,4,7]$.
Сегодня на реализацию геномных исследований разных видов сельскохозяйственных животных, которые ведут более чем в двух десятках стран, выделяются значительные средства. При этом бюджет этих исследований составляет сотни миллионов долларов. Чтобы иметь возможность сопоставить генотипы большего количества животных и определить наличие связей между известными точечными мутациями (SNP) и показателями племенной ценности, многие зарубежные молекулярно-генетические лаборатории объединяют усилия, создавая единую базу данных [10].

Таким образом, ДНК-диагностика - актуальное направление фундаментальной и прикладной биотехнологии, которое позволяет перевести селекцию свиней на качественно новый уровень и получить объективный прогноз продуктивности на основе истинного генетического потенциала животных.

Цель нашей работы - изучение продуктивности хряков-производителей в зависимости от породы и генетического профиля по ДНК-маркерам: ген рианодинового рецептора (RYR-1), ген эстрагенового рецептора (ESR), ген мясной продуктивности (Н-FABP).

Методика исследований. Работу выполняли сотрудники ВНИИОК - филиала ФГБНУ «Северо-Кавказский ФНАЦ» на базе ООО «СВК» Красногвардейского района, $3 \mathrm{AO}$ «Совхоз имени Кирова» Труновского района, СХПК «Россия» Новоалександровского района Ставропольского края в 2017 г. В ООО «СВК» исследовали 13 хряков-производителей с кровностью 50 \% дюрок $\times$ $\times 50 \%$ пьетрен, в $3 \mathrm{AO}$ «Совхоз имени Кирова»12 скороспелой мясной породы (CM-1) и в СХПК «Россия» - 31 крупной белой породы.

Анализ генетического профиля проводили на хряках-производителях по следующим ДНК-маркерам: ген рианодинового рецептора (RYR-1), ген эстрагенового рецептора (ESR), ген мясной продуктивности (Н-FАВР).

Выделение ДНК из образцов крови было проведено набором реагентов DIAtom ${ }^{\mathrm{TM}} \mathrm{DNA}$ Prep 100. Полиморфизм генов стрессчувствительности (RYR-1), плодовитости (ESR) и мясности (H-FABP) изучали методом полимеразной цепной реакции (ПЦР), согласно методикам с использованием праймеров, подобранных таким образом, чтобы фрагмент ДНК между ними включал в себя сайты узнавания, специфичные для аллельных вариантов генов. Амплификацию проводили при помощи наборов реагентов для PCR амплификации ДНК - GenePak PCR Core. Амплифицированные продукты подвергались рестрикции соответствующими эндонуклеазами и разделению электрофорезом в 2,0\%-м агарозном геле, с последующей идентификацией в ультрафиолетовом свете на трансиллюминаторе и с использованием программы Gen Imager. 
Индекс оценки откормочных и мясных качеств свиней рассчитывали по формуле:

$\mathrm{O}_{100}=1,3\left(200-\mathrm{X}_{\mathrm{a}}\right)+0,1\left(\mathrm{X}_{6}-650\right)+67(4,1-$ $\left.-\mathrm{X}_{\mathrm{B}}\right)+2\left(\mathrm{X}_{\mathrm{r}}-93\right)+4\left(33-\mathrm{X}_{\mathrm{r}}\right)+15\left(\mathrm{X}_{\mathrm{e}}-10,2\right)$, где $\mathrm{X}_{\mathrm{a}}$ - возраст достижения 100 кг живой массы; $\mathrm{X}_{6}$ - среднесуточный прирост; $\mathrm{X}_{\mathrm{B}}$ - затраты корма; $\mathrm{X}_{\mathrm{r}}$ - длина туши; $\mathrm{X}_{\text {д }}$ - толщина шпика; $\mathrm{X}_{\mathrm{e}}$ масса задней трети полутуши.

Результаты исследований. В результате проведенного генотипирования хряков-производителей (кровность $50 \%$ дюрок $\times 50$ \% пьетрен) в ООО «СВК» было установлено, что все животные стрессоустойчивы (ген RYR-1), а по гену мясности (H-FABP) выявлено четыре генотипа - HHDd, HhDd, HHDD и HhDD. Результаты контрольного откорма подсвинков в разрезе генотипов хряков по генам RYR-1 и H-FABP представлены в табл. 1.

Животные с генотипом HHDd (I группа) превосходят аналогов II, III и IV групп по среднесуточному приросту на 8-49 г, следовательно, и по возрасту достижения живой массы 100 кг на 2-6 дней. Достоверно меньшее отложение подкожного жира отмечено у подсвинков I группы, y них генотип Dd гена H-FABP находился в гетерозиготной форме. Так, у молодняка свиней I группы толщина шпика была меньше, чем во II, III и IV группах на 4,0-8,0 \% $(P>0,95)$. Отмечено положительное влияние доминирующей (желательной) формы генотипа НH (I группа) на массу окорока и площадь «мышечного глазка». Они были выше, чем во II-IV группах в среднем на $3,0-6,1 \%$.

Индекс мясных и откормочных качеств, который включает в себя 6 основных показателей продуктивности животных, наглядно свидетельствует о преимуществе подсвинков I группы (HHDd) над сверстниками других вариантов полиморфизма. Различия варьировали от 12 до 42 баллов.

Анализ влияния генотипов генов RYR-1 и H-FABP на продуктивность подсвинков, полученных от хряков-производителей различных генотипов скороспелой мясной породы (CM-1) в $3 \mathrm{AO}$ «Совхоз имени Кирова» (метод контрольного откорма), показал, что варианты с генотипом NNHhDd превосходят по возрасту достижения живой массы 100 кг аналогов II группы на 2 суток. Среднесуточный прирост у молодняка I группы был выше на 8 г (табл. 2).

Установлено достоверное отличие в отложении подкожного жира у подсвинков I группы, у которых генотипы гена H-FABP находились в рецессивной форме. Так, I группа молодняка свиней превосходила аналогов II группы по толщине шпика на 4,2 \%. Отмечено положительное влияние генов H-FABP и RYR-1 с желательными генотипами HhDd и NN на массу окорока и площадь «мышечного глазка».

Объективная оценка откормочных и мясных 
качеств по сумме 6 основных показателей, выраженных в индексе, наглядно свидетельствует о преимуществе животных I группы над сверстниками другого варианта полиморфизма, разница составила 32 балла. Для оценки продуктивности свиней крупной белой породы григорополисского типа (КБ ГТ)в СХПК «Россия» был проведен контрольный откорм подсвинков, полученных от хряков различных генотипов гена H-FABP (табл. 3).

Животные с генотипом HHDd (I группа) превосходят аналогов II, III и IV групп по среднесуточному приросту на 11-30 г и по возрасту достижения живой массы 100 кг на 1-3 дня. Достоверно меньшее отложение подкожного жира отмечено у подсвинков I группы, у которых генотип Dd гена H-FABP находился в гетерозиготной форме. Так, у молодняка свиней I группы толщина шпика была меньше, чем во II, III и IV группах, на 4,5-9,0 \% $(P>0,95)$. Показано положительное влияние доминирующей (желательной) формы генотипа НH (I группа) на массу окорока и площадь «мышечного глазка». Они были выше, чем во II-IV группах, в среднем на 2,9-4,2 \%.

Индекс мясных и откормочных качеств $\left(\mathrm{O}_{100}\right)$, который включает в себя 6 основных показателей продуктивности животных, наглядно свидетельствует о преимуществе подсвинков I группы (HHDd) над сверстниками других вариантов полиморфизма. Различия варьировали от 14 до 32 баллов. Однако следует отметить, что данный генотип присутствует у 21,0 \% животных, а у основной массы разница в продуктивных качествах практически нивелируется в пределах ошибки. Таким образом, при ведении селекционного процесса в племзаводе СХПК «Россия», а также при приобретении хряков-производителей для репродукторных ферм предпочтение необходимо отдавать животным-носителям генотипов HHdd и HHDd гена H-FABP.

Среди множества факторов интенсификации свиноводства особое место принадлежит целенаправленному выращиванию и всесторонней оценке продуктивных качеств, по результатам которой проводится отбор наилучших хряков-производителей как основных особей в воспроизводстве свиней. Половое созревание у хряков - медленный процесс, в результате которого образование спермы и половое влечение проявляются одновременно, начиная с 4-месячного возраста.

Ранее проведенные исследования показали, что рост хряка заканчивается к концу первого года жизни, поэтому увеличение общего количества семенной жидкости и спермопродукции сопровождается не только развитием половой зрелости, но и увеличением массы тела. Величина семенников положительно коррелируется с общим объемом спермы и возрастает пропорционально общему размеру тела. Сперму успешно получали от хрячков 5-месячного возраста. Но как по объему, так и по содержанию незрелых и неполноценных сперматозоидов такая сперма значительно хуже, чем у зрелых хряков. Кроме того, авторы не исключают влияние генетических различий на становление половой зрелости у хряков различных пород.

Генотипирование хряков-производителей с кровностью (50\% дюрок× 50 \% пьетрен) в OOO «СВК» по гену воспроизводства (ESR) показало, что животные подразделяются на два генотипа - гетерозиготный $\mathrm{AB}$ и гомозиготный (желательный) генотип ВВ. Результаты оценки спермопродукции хряков (табл. 4) показали на незначительное превосходство хряков ВВ генотипа гена ESR по объему эякулята и концентрации сперматозоидов. Однако количество прямолинейно подвижных сперматозоидов у хряков гомозиготного генотипа (BВ) эстрагенового рецептора составило 44,7 млрд на эякулят, что на 6,2 \% больше, чем у гетерозиготного генотипа (AB).

Влияние разного аллельного состояния гена эстрагенового рецептора (ESR) на воспроизводительные качества хряков представлено в табл. 5.

У хряков различных генотипов установлены различия по таким показателям, как оплодотворяемость свиноматок (на 6,9 \%), рождение живых поросят (0,5 поросенка), сохранность $(2,2 \%)$ в пользу животных с гомозиготным ВВ генотипом. В то же время основная масса (90\%) хряков-производителей в ООО «СВК»носители гетерозиготного АВ генотипа.

По результатам генотипирования хряков-производителей породы СМ-1 в ЗАО «Совхоз имени Кирова» было установлено, что в воспроизводящей части стада желательный генотип BB гена ESR присутствует у 25,0 \% животных, а 75 \% - носители генотипа АВ. В то же время отмечали высокое содержание аллеля В $(0,625)$ в генотипах гена ESR у данной породы. Таким образом, высока вероятность наследования генотипа ВВ (желательный по воспроизводству) у потомства от данных хряковпроизводителей. Кроме того, выявлено влияние разного аллельного состояния гена эстрагенного рецептора на воспроизводительные качества хряков породы СМ-1 (табл. 6).

У генотипированных хряков установлены различия по таким показателям, как оплодотворяемость свиноматок (на 7,1 \%), рождение живых поросят (0,4 поросенка), сохранность $(2,9 \%)$ в пользу животных с гомозиготным ВВ генотипом. Генотипирование хряков-производителей крупной белой породы в СХПК «Россия» по гену воспроизводства (ESR) показало, что животные подразделяются на два генотипа гетерозиготный $\mathrm{AB}$ и гомозиготный (желательный) генотип ВВ. Нежелательный гомозиготный генотип AА не выявлен. Кроме того, все животные по гену (RYR-1) стрессоустойчивые. Воспро- 

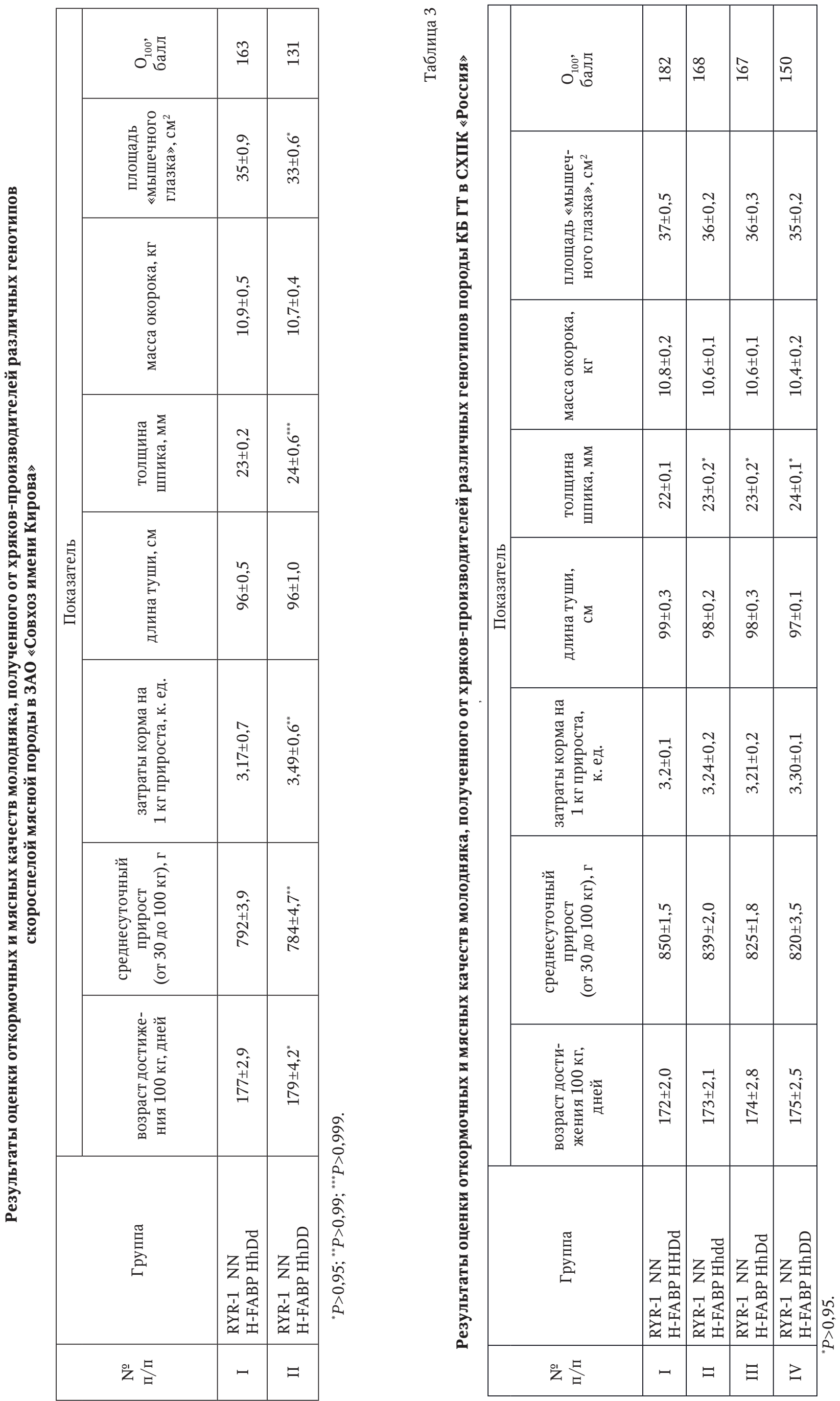
Показатели спермопродукции хряков-производителей в возрасте 12-13 месяцев в зависимости от генотипов гена ESR в 000 «СК»

\begin{tabular}{|l|c|c|}
\hline \multicolumn{1}{|c|}{ Показатель } & \multicolumn{2}{|c|}{ Генотип } \\
\cline { 2 - 3 } & $\mathrm{AB}$ & $\mathrm{BB}$ \\
\hline Количество хряков, гол. & $270,5 \pm 7,4$ & $276,3 \pm 6,3$ \\
\hline Объем эякулята, мл & 0,22 & 0,23 \\
\hline Концентрация сперматозоидов, млрд/мл & 59,5 & 63,5 \\
\hline Общее количество сперматозоидов в эякуляте, млрд & 38,1 & 44,7 \\
\hline Общее количество прямолинейно подвижных сперматозоидов в эякуляте: & \\
млрд & 64,2 & 70,4 \\
\hline Подвижность сперматозоидов, балл & 8,5 & 9,0 \\
\hline Количество спермадоз на эякулят, шт. & 9,5 & 11,0 \\
\hline
\end{tabular}

Влияние гена ESR на воспроизводительные качества хряков-производителей (Д $\times$ П) различных генотипов в 000 «СК»

\begin{tabular}{|l|c|c|}
\hline \multicolumn{1}{|c|}{ Показатель } & Генотип \\
\cline { 2 - 3 } & $\mathrm{AB}$ & $\mathrm{BB}$ \\
$\mathrm{M} \pm \mathrm{m}$
\end{tabular}

Таблица 6

Влияние гена ESR на воспроизводительные качества хряков-производителей различных генотипов скороспелой мясной породы в 3 АО «Совхоз имени Кирова»

\begin{tabular}{|l|c|c|}
\hline \multicolumn{1}{|c|}{ Показатель } & АВ & Генотип \\
\cline { 2 - 3 } & $\mathrm{M} \pm \mathrm{m}$ & $\mathrm{MB}$ \\
\hline Оплодотворяемость свиноматок, \% & 75,2 & 82,3 \\
\hline Количество рожденных живых поросят, гол. & $10,8 \pm 0,2$ & $11,2 \pm 0,1$ \\
\hline Крупноплодность, кг & $1,32 \pm 0,1$ & $1,3 \pm 0,1$ \\
\hline Сохранность, \% & 88,7 & 91,6 \\
\hline
\end{tabular}

изводительные качества хряков представлены в табл. 7.

Проведенное генотипирование хряков-производителей позволило установить преимущество гомозиготного генотипа (BB) по оплодотворяемости на 6,8 \% и сохранности поросят в 30-дневном возрасте на 3,0 \%. Данная закономерность прослеживается во всех хозяйствах независимо от способа осеменения (покрытия) животных и породного состава хряков.

На основе полученных данных можно констатировать, что созданный генофонд отцовских генотипов в регионе вполне конкурентоспособен для реализации более перспективных и масштабных проектов выведения специализированных типов свиней с привлечением незначительного контингента импортных интенсивных мясных пород.

Заключение. Полученные данные подтверждают целесообразность проведения генетической диагностики воспроизводящей части стада, как хряков так и свиноматок, которая позволит объективно выявлять предпочтительные для селекции аллели. Отбор таких животных в качестве родительских пар значительно повысит продуктивность животных в регионе.

Однако помимо генной диагностики желательно при включении хряков-производителей в воспроизводительный процесс учитывать количественные и качественные показатели спермопродукции, исходя из реального возраста животных и породности, а не руководствоваться только экстерьерными и весовыми показателями.

По результатам раннее проведенных наблюдений и последующих исследований хозяйственно-полезных признаков продуктивности в разрезе аллельных систем следует уточнить, что предпочтительными с точки зрения селекции являются генотипы BB (ген ESR), HHdd(ген HFABR) и NN(ген RYR-1). Генотипы AB, HhDd и Nn выше указанных генов являются промежуточными для селекции, а генотипы AA, hhDD и 
Влияние гена ESR на воспроизводительные качества хряков-производителей различных генотипов крупной белой породы в СХПК «Россия»

\begin{tabular}{|l|c|c|}
\hline \multicolumn{1}{|c|}{ Показатель } & СВ & Генотип \\
\cline { 2 - 3 } & $\mathrm{M} \pm \mathrm{m}$ & $\mathrm{BB}$ \\
$\mathrm{M} \pm \mathrm{m}$
\end{tabular}

nn - нежелательными или недопустимыми для дальнейшей селекции.

Традиционные методы селекции, в значительной степени дополненные генетическими маркерами, позволяют вести оценку, отбор и подбор особей с желательными генотипами гораздо эффективнее.

Материалы статьи представляют практическую ценность для научных работников, селекционеров и специалистов свиноводческих хозяйств, так как традиционные методы селекции, в значительной степени дополненные генетическими маркерами, позволяют эффективнее вести оценку, отбор и подбор особей с желательными генотипами.

\section{СПИСОК ЛИТЕРАТУРЫ}

1. Зацуаринин А.А. Качественные показатели жировой ткани свиней крупной белой породы различного происхождения // Аграрный научный журнал. - 2016. - № 1. - С. 7-9.

2. Оценка воспроизводительных качеств свиней на основе генетических маркеров / М.И. Селионова [и др.] // Свиноводство. - 2014. - № 7. - С. 17-19.

3. Погодаев В., Панасенко В., Пономарев О. Качество мяса свиней степного типа скороспелой породы (СМ-1) // Свиноводство. - 2002. - № 2. - С. 13-15.

4. Погодаев В.А., Пешков А.Д., Шнахов А.М. Результативность откорма свиней, полученных на основе пород СМ-1 и ландрас французской и канадской селекции // Зоотехния. - 2011. - № 1. C. 23-24.
5. Смарагдов М.Г. Тотальная геномная селекция с помощью SNP как возможный ускоритель традиционной селекции // Генетика. - 2009. - Т. 45. - № 6. C. 725-728.

6. Genomic imputation and evaluation using high density Holstein genotypes /P.M.VanRaden, D.J.Null, M.Sargolzael et al. // J. Dairy Sci, 2013, V. 96, P. 668-678.

7. Goddard M.E. Genomic selection /M.E. Goddard and B.J.Hayes // Journal of Animal Breeding and Genetics, 2007, V. 124, P. 323-330.

8. Meuwissen T.H.E. Genomic selection: The future of animal breeding. /T.H.E. Meuwissen // Norwegian University of Life Sciences, Box 5003, 1432 As Norway, 2007, P. 88-91.

9. Haley C.S., VisscherP.M.Strategies to utilize marker-quantitativetraitlociassociations //J.DairySci,1998, V. 81, No. 2, P. 85-97.

10. VanRaden P.M., SullivanP.G.International genomic evaluation methods for dairy cattle// Genet. Selec. Evol., 2010,V. 42, P. 7.

Погодаев Владимир Аникеевич, $\partial-p$ c.- $x$. наук, проф., главный научный сотрудник, ВНИИОК - филиал ФГБНУ «Северо-Кавказский Федеральный научный аграрный центр». Россия.

Рачков Игорь Геннадьевич, $\partial-p$ c.-х. наук, ведущий научный сотрудник, ВНИИОК - филиал ФГБНУ «Северо-Кавказский Федеральный научный аграрный центр». Россия.

355017, г. Ставрополь, пер. Зоотехнический, 15.

Тел.: 89187567539.

Ключевые слова: хряки-производители; продуктивность; ДНК-диагностика; генотип; генетические маркеры.

\section{INFLUENCE OF BREED AND GENOTYPE ON PRODUCTIVE QUALITIES OF BREEDING BOARS}

Pogodaev Vladimir Anikeevich, Doctor of Agricultural Sciences, Professor, Senior Re-searcher, VNIIOK - branch of Federal State Scientific Institution "North-Caucasian Federal Scientific Agrarian Centre”. Russia.

Rachkov Igor Gennadievich, Doctor of Agricultural Sciences, Chief Researcher VNIIOK - branch of Federal State Scientific Institution "North-Caucasian Federal Scientific Agrarian Centre”. Russia.

Keywords: pigs; productivity; DNA diagnosis; genotype; genetic markers.

The article is aimed at identifying the productivity of breeding boars depending on the breed and the genetic profile on the DNA markers: the ryanodine receptor gene (RYR-1), the estrogen receptor gene (ESR), the meat production gene (FABP). The leading method to an estimation of this problem is the breeding value evaluation of animal based on DNA markers, which allows us to obtain the information on the genotype of the animal and its productive qualities. The ar- ticle presents data confirming the expediency for genetic diagnosis in the reproducing part of the herd both boars and sows, which allow us objectively to identify the alleles preferred for breeding. Selection of such animals as parental pairs will significantly increase the productivity of pigs. Besides gene diagnosis, it is desirable at inclusion of the breeding boars in the reproductive process to take into account the quantitative and qualitative indicators of sperm production proceeding from real age of the animals and their breed, rather than being guided by exterior and weight indices. Preferred from the point of view of breeding are such genotypes as BB (ESR gene), HHdd (H-FABR gene) and NN (RYR-1 gene). The AB, HhDd and Nn genotypes of above-mentioned genes are intermediate for selection, and $A A, h h D D$ and nn are undesirable and unacceptable for further selection. The materials of the article are of the of practical value for scientific workers, breeders and specialists in pig farms, since traditional methods of breeding largely supple-mented by genetic markers, allow the evaluation, selection and choice of individuals with the desired genotypes to be more efficient. 